\title{
Human Growth Hormone Prevents the Protein Catabolic Side Effects of Prednisone in Humans
}

Fritz F. Horber and Morey W. Haymond

Department of Pediatrics, Endocrine Research Unit, Mayo Clinic and Foundation, Rochester, Minnesota 55905; and Medizinische Universitaets Poliklinik, Inselspital Bern, 3010 Bern, Switzerland

\begin{abstract}
Prednisone treatment causes protein wasting and adds additional risks to a patient, whereas human growth hormone (hGH) treatment causes positive nitrogen balance. To determine whether concomitant administration of hGH prevents the protein catabolic effects of prednisone, four groups of eight healthy volunteers each were studied using isotope dilution and nitrogen balance techniques after $7 \mathrm{~d}$ of placebo, hGH alone $\left(0.1 \mathrm{mg} \cdot \mathrm{kg}^{-1} \cdot \mathrm{d}^{-1}\right)$, prednisone alone $\left(0.8 \mathrm{mg} \cdot \mathrm{kg}^{-1} \cdot \mathrm{d}^{-1}\right)$, or prednisone plus hGH ( $n=8$ in each group). Whether protein balance was calculated from the leucine kinetic data or nitrogen balance values, prednisone alone induced protein wasting $(P<0.001)$, whereas hGH alone resulted in positive $(P$ $<0.001)$ protein balance, when compared to the placebotreated subjects. When hGH was added to prednisone therapy, the glucocorticoid-induced protein catabolism was prevented. Using leucine kinetic data, negative protein balance during prednisone was due to increased $(P<0.05)$ proteolysis, whereas hGH had no effect on proteolysis and increased ( $P$ $<0.01$ ) whole body protein synthesis. During combined treatment, estimates of proteolysis and protein synthesis were similar to those observed in the placebo treated control group. In conclusion, human growth hormone may have a distinct role in preventing the protein losses associated with the administration of pharmacologic doses of glucocorticosteroids in humans. (J. Clin. Invest. 1990. 86:265-272.) Key words: leucine $\bullet \alpha$ ketoisocaproate - radioactive tracers $\bullet$ stable isotopic tracers • insulin-like growth factor I
\end{abstract}

\section{Introduction}

Patients treated with glucocorticoids over prolonged periods of time have protein wasting, poor tissue healing, and an increased incidence of infections (1-5). The ongoing and, on occasion, severe losses of body protein (4) remain a major concern in the management of patients receiving glucocorticosteroid therapy. Identification of the factors leading to glucocorticosteroid-induced protein losses and of therapeutic modalities which might ameliorate (6-8) or prevent these losses may have major implications for the management of the large numbers of patients receiving long-term glucocorticoid ther-

This study was presented in part at the 46th Annual Meeting of the American Society for Clinical Investigation, Washington DC, 1989.

Address reprint requests to Morey W. Haymond, Nemour's Children's Clinic, Box 5720, Jacksonville, FL 32247.

Received for publication 4 December 1989 and in revised form 5 March 1990.

J. Clin. Invest.

(C) The American Society for Clinical Investigation, Inc.

0021-9738/90/07/0265/08 \$2.00

Volume 86, July 1990, 265-272 apy (e.g., allograft recipients, patients with autoimmune, dermatologic, or asthmatic diseases, etc.).

In the past, nitrogen balance measurements have been used to gain insights into protein metabolism; however, such measurements only allow estimates of net changes in whole body protein. In contrast, using isotope tracers of the essential amino acid leucine (which represents $8 \%$ of whole body proteins [9]) and isotope dilution methodology, rates of protein breakdown and protein synthesis can be measured in addition to estimates of protein balance (10).

In humans, short-term infusion of cortisol sufficient to increase plasma cortisol concentrations to the high physiologic range increases the plasma concentrations of amino acids, particularly those of the branched-chain amino acids (leucine, isoleucine, and valine) $(11,12)$. The rate of appearance of leucine in the postabsorptive state is increased, suggesting an increased rate of whole body proteolysis (12). In normal volunteers short-term high dose prednisone therapy $(\sim 60 \mathrm{mg} / \mathrm{d})$ results in negative leucine balance in both the fasted and fed states when compared to the same subjects treated with placebo (13). These data provide clear evidence that even during short periods of exposure $(5 \mathrm{~d})$, high dose glucocorticoid therapy has deleterious effects on whole body protein metabolism.

Human growth hormone ( $\mathrm{hGH})^{1}$ is a potent anabolic agent known to stimulate linear height in growth hormone deficient children (14) and protein synthesis as well as cell growth in vitro (15). In the past, the amount of $\mathrm{hGH}$ available from cadaver pituitary glands was insufficient to treat all children with known hGH deficiency and precluded exploration of its effects in a variety of disease states in adults. However, the commercial availability of recombinant DNA human growth hormone (rhGH) has made such studies possible. These studies have demonstrated improved nitrogen balance in hypercatabolic burn patients $(16,17)$, in normal volunteers during hypocaloric intravenous feeding (18), in calorically restricted obese volunteers $(19,20)$, in patients during parenteral nutrition (21), and in highly trained athletes (22).

Thus, the purpose of the present investigation was to determine whether concomitant daily injections of rhGH during short-term, high-dose administration of the glucocorticoid prednisone may reverse the protein catabolic state observed in subjects receiving prednisone alone.

\section{Methods}

\section{Subjects}

After review and approval of the protocol by the Mayo Institutional Review Board and the Clinical Research Center Advisory Committee,

1. Abbreviations used in this paper: hGH, human growth hormone; IGF-I, insulin-like growth factor I; KIC, $\alpha$-ketoisocaproate; LBM, lean body mass; NOLD, nonoxidative leucine disappearance; rhGH, recombinant DNA human growth hormone; SA, specific activity. 
informed consent was obtained from 32 healthy adult volunteers who were between the ages of 18 to $36 \mathrm{yr}$ and within $6 \%$ of their ideal body weight (see Table I). None had a family history of diabetes mellitus in first degree relatives, gastritis, peptic ulcer disease, or history of gastrointestinal bleeding. All had a normal 2-h postprandial plasma glucose concentration after a meal containing at least $100 \mathrm{~g}$ of glucose to exclude possible underlying carbohydrate intolerance. Only subjects with normal hematology, chemistry, urinalysis, and plasma thyroxine values were enrolled into the study. These laboratory values did not change as a result of drug or placebo therapy (see below).

\section{Protocol}

Subjects were randomized into one of four study groups (eight subjects per group) and received oral tablets and injections in a single blinded fashion under the supervision of the nursing staff of the Mayo CRC. Group I served as controls (placebo lactose tablets and saline injections). Group II (prednisone tablets and saline injections) received prednisone orally in three equal doses $15 \mathrm{~min}$ before breakfast, lunch, and dinner for $7 \mathrm{~d}$ at a dose of $0.8 \mathrm{mg} \cdot \mathrm{kg}^{-1} \cdot \mathrm{d}^{-1}$. Group III (placebo tablets and subcutaneous injections of rhGH, $0.1 \mathrm{mg} \cdot \mathrm{kg}^{-1} \cdot \mathrm{d}^{-1}$ ) received $\mathrm{rhGH} 15 \mathrm{~min}$ before dinner (daily alternation between both thighs) for $7 \mathrm{~d}$ before the study and for the $\mathbf{3} \mathrm{d}$ of inpatient study. Group IV (prednisone tablets and rhGH injections) received prednisone and rhGH as described for groups II and III, respectively.

The subjects consumed only a prescribed diet of $35 \mathrm{kcal} \cdot \mathrm{kg}^{-1} \cdot \mathrm{d}^{-1}$ containing $\sim 53 \%, 29 \%$, and $18 \%$ carbohydrate, fat and protein, respectively, for $7 \mathrm{~d}$ in the Clinical Research Center. Each subject consumed identical daily meals at breakfast, lunch, and dinner, and was required to eat everything provided and not to eat off the Unit. Throughout the study, 24-h urine and stool collections were obtained to determine nitrogen balance and urinary creatinine excretion. In addition, on each of the days, plasma glucose and creatinine concentrations were determined.

Subsequently, all subjects were admitted to the Mayo Clinical Research Center in the afternoon of the seventh treatment day and were hospitalized for the next $3 \mathrm{~d}$. At $\sim 1700$ hours on the day of admission, ${ }^{3} \mathrm{H}_{2} \mathrm{O}(20 \mu \mathrm{Ci})$ was administered orally to each subject and urine was collected before and after 2,4 , and $6 \mathrm{~h}$ to determine whole body water specific activity (SA) from which lean body mass (LBM) was calculated as previously described (23). At $\sim 1730$ hours on the afternoon of admission, an intravenous catheter was placed in an antecubital vein and a continuous infusion of prednisolone $\left(0.8 \mathrm{mg} \cdot \mathrm{kg}^{-1} \cdot \mathrm{d}^{-1}\right.$, groups II and IV) or $0.9 \%$ saline (Group I and III) was started and continued throughout the three inpatient study days.

Three different study protocols (A, B, and C) were carried out over the $3 \mathrm{~d}$ of hospitalization in each subject (see below). After completion of each study, subjects received their full daily diet in two meals.

\section{Studies}

Study A. Study A was designed to: (a) assess the effects of hGH and/or prednisone on whole body proteolysis (as estimated by the rate of leucine appearance using $\left[1-{ }^{14} \mathrm{C}\right]$ leucine), leucine oxidation (corrected for individual $\mathrm{CO}_{2}$ fixation using steady-state sodium $\left[{ }^{14} \mathrm{C}\right]$ bicarbonate infusions), and whole body protein synthesis (which was calculated by subtracting leucine oxidation from the rate of appearance of leucine) in the postabsorptive state; $(b)$ trace the systemic entry from the gastrointestinal tract and oxidation of leucine in the postabsorptive state by infusing $\left[1-{ }^{13} \mathrm{C}\right]$ leucine via a constant enteral infusion; and $(c)$ control for the constancy of absorption of a hydrogen labeled tracer in experiments $A, B$, and $C$ by infusion $\left[{ }^{3} \mathrm{H}\right]$ leucine via the enterally placed tube.

At 0330 hours the morning after admission, the exact body weight was obtained and another intravenous site was established in a contralateral hand vein for arterialized-venous blood sampling $(24,25)$. At 0400 hours, a primed, constant infusion of sodium $\left[{ }^{14} \mathrm{C}\right]$ bicarbonate $(5$ $\mu \mathrm{Ci}$ and $0.08 \mu \mathrm{Ci} \cdot \mathrm{kg}^{-1} \cdot \mathrm{min}^{-1}$ ) was initiated and continued for $3.5 \mathrm{~h}$ to estimate the fractional recovery of ${ }^{14} \mathrm{CO}_{2}$ in breath. After 0600 hours, breath samples (but no blood samples) were collected every $20 \mathrm{~min}$. At $\sim 0730$ hours, a standard enteral feeding tube $(8$ French, $109 \mathrm{~cm}$
[Keofeed; IVAC, San Diego, CA]) was placed via the nose into the duodenum. A primed constant intravenous infusion of $\left[1-{ }^{14} \mathrm{C}\right]$ leucine (group I, 9.3 \pm 0.4 ; group II, 10.2 \pm 1.1 ; group III, 14.9 \pm 1.1 ; and group IV, $10.6 \pm 1.4 \times 10^{3} \mathrm{dpm} \cdot \mathrm{kg} \mathrm{LBM}^{-1} \cdot \mathrm{min}^{-1}$, respectively) was initiated at $\sim 0800$ hours and continued for $6 \mathrm{~h}$. In addition, tracer amounts of $\left[1-^{13} \mathrm{C}\right]$ leucine (group I, $53 \pm 3$; group II, $49 \pm 3$; group III, $50 \pm 2$; and group IV, $50 \pm 2 \mathrm{nmol} \cdot \mathrm{kg} \mathrm{LBM}^{-1} \cdot \mathrm{min}^{-1}$, respectively) and $\left[4,5-{ }_{-}^{3} \mathrm{H}\right]-$ leucine (group I, 17.9 \pm 2.5 ; group II, 18.2 \pm 2.9 ; group III, 24.9 \pm 1.8 ; and group IV, $16.3 \pm 2.5 \times 10^{3} \mathrm{dpm} \cdot \mathrm{kg} \mathrm{LBM}^{-1} \cdot \mathrm{min}^{-1}$, respectively) were infused at a constant rate via the enteral tube over the $6 \mathrm{~h}$ of study. These latter isotopes were added to the enteral infusions to trace the systemic entry of the amino acids and to permit the partitioning of the circulating leucine into endogenous and exogenous components. The higher rates of $\left[{ }^{3} \mathrm{H}\right]$ and $\left[{ }^{14} \mathrm{C}\right]$ leucine were necessary because of the lower plasma concentrations of both leucine and KIC observed during rhGH treatment. In addition, $0.45 \%$ saline was infused at $160 \mathrm{ml} / \mathrm{h}$ using a Travenol infusion pump, a volume equal to that of the test meal infused in studies B and C (see below). After $4 \mathrm{~h}$ of isotope infusion, blood and breath samples were obtained at 20-min intervals for the remaining $2 \mathrm{~h}$ (see below).

Study B. Study B was designed to: (a) assess the effects of hGH and/or prednisone on whole body proteolysis (as estimated by the rate of leucine appearance using $\left[1-{ }^{14} \mathrm{C}\right]$ leucine), leucine oxidation, and whole body protein synthesis in the fed state; $(b)$ quantitate in the fed state (at isotope and substrate steady state) the systemic entry and oxidation of enterally infused leucine in a "meal" consisting of amino acids and glucose by infusing $\left[1-{ }^{13} \mathrm{C}\right]$ leucine via a constant enteral infusion; and $(c)$ quantitate the endogenous rate of appearance of leucine by subtracting the infusion rate of cold leucine from the total rate of appearance of leucine to the plasma space.

Study B was carried out in an identical fashion to that of study A except that $(a)$ a solution containing glucose and mixed amino acids (Travasol; Clintec Nutrition, Deerfield, IL) was infused at a rate to deliver $5.3 \pm 0.1 \mathrm{mg} \cdot \mathrm{kg} \mathrm{LBM}{ }^{-1} \cdot \mathrm{min}^{-1}$ of glucose and $1.1 \pm 0.1$ $\mu \mathrm{mol} \cdot \mathrm{kg} \mathrm{LBM}^{-1} \cdot \mathrm{min}^{-1}$ of leucine. A total of $10 \mathrm{kcal}$ per kilogram of body weight was infused over the $6 \mathrm{~h}$ of study to simulate the fed state; and $(b)$ the infusion rates of the radiolabeled isotopes used in study $\mathrm{A}$ (see above) were increased in groups receiving prednisone $\left(\left[1-{ }^{14} \mathrm{C}\right]-\right.$ leucine: group I, $8.9 \pm 0.3$; group II, $14.5 \pm 1.1$; group III, $15.9 \pm 1.3$; and group IV, $14.6 \pm 0.8 \times 10^{3} \mathrm{dpm} \cdot \mathrm{kg} \mathrm{LBM}{ }^{-1} \cdot \mathrm{min}^{-1}$, respectively; $\left[{ }^{3} \mathrm{H}\right]-$ leucine: group I, $14.4 \pm 0.7$; group II, $22.5 \pm 2.3$; group III, $26.5 \pm 2.3$; and group IV, $26.2 \pm 2.8 \times 10^{3} \mathrm{dpm} \cdot \mathrm{kg} \mathrm{LBM}{ }^{-1} \cdot \mathrm{min}^{-1}$, respectively; [1- $\left.{ }^{13} \mathrm{C}\right]$ leucine: group I, $53 \pm 3$; group II, $48 \pm 3$; group III, $49 \pm 4$; and group IV, $49 \pm 3 \mathrm{nmol} \cdot \mathrm{kg} \mathrm{LBM}^{-1} \cdot \mathrm{min}^{-1}$, respectively).

Study $C$. Study C was designed to: (a) control for the production of ${ }^{13} \mathrm{CO}_{2}$ derived from the oxidation of the enterally absorbed glucose and thus avoiding an overestimation in the rate of leucine oxidation from the enterally absorbed leucine in study B. No $\left[{ }^{13} \mathrm{C}\right]$ tracer was infused during this study; $(b)$ correct leucine oxidation for the individual $\mathrm{CO}_{2}$ recovery in the fed state steady-state by infusing sodium $\left[{ }^{14} \mathrm{C}\right]$ bicarbonate throughout the study; and $(c)$ assure that the subjects were studied under comparable conditions in studies $A$ and $B$ by infusing $\left[{ }^{3} \mathrm{H}\right]$ leucine intravenously and $\left[{ }^{2} \mathrm{H}_{3}\right]$ leucine via the enterally placed tube.

This study was carried out in an identical fashion to that of study $B$ except that $(a)$ no $\left[{ }^{14} \mathrm{C}\right]$ leucine or $\left[{ }^{13} \mathrm{C}\right]$ leucine was administered; $(b)$ $\left[4,5^{3} \mathrm{H}\right]$ leucine was infused intravenously (group I, $10.2 \pm 0.5$; group II, $10.9 \pm 0.8$; group III, $12.5 \pm 0.7$; and group IV, $13.3 \pm 0.8 \times 10^{3} \mathrm{dpm} \cdot \mathrm{kg}$ $\mathrm{LBM}^{-1} \cdot \mathrm{min}^{-1}$, respectively) and $\left[5,5,5-{ }^{2} \mathrm{H}_{3}\right]$ leucine (group I, $41 \pm 2$; group II, 38 \pm 3 ; group III, $34 \pm 2$; and group IV, $40 \pm 4 \mathrm{nmol} \cdot \mathrm{kg}$ $\mathrm{LBM}^{-1} \cdot \mathrm{min}^{-1}$, respectively) was infused with the meal; and (c) sodium $\left[{ }^{14} \mathrm{C}\right]$ bicarbonate was infused throughout the entire study period (i.e., for $10 \mathrm{~h}$ ).

Study B and study $\mathrm{C}$ were carried out in random order.

\section{Blood and breath sampling in studies $A, B$ and $C$}

Blood (17 ml) and breath samples were collected at each sampling time $(0,260,280,300,320,340$, and $360 \mathrm{~min})$ in all studies (A, B, and C) At time point 0,240 , and 360 , an additional $6 \mathrm{ml}$ of blood was drawn to determine the plasma concentrations of glucose (YSI glucose ana- 
lyzer [Yellow Springs Instrument Co., Yellow Springs, $\mathrm{OH}$ ]), insulin, hGH, and insulin-like growth factor I (IGF-I, kindly determined by Dr. R. Hintz) (26-29). Blood samples were placed on ice, centrifuged at $4^{\circ} \mathrm{C}$, and the plasma stored at $-70^{\circ} \mathrm{C}$ until analyzed.

\section{Procedures}

ISOTOPES

L- $\left[1-{ }^{13} \mathrm{C}\right]$ leucine (Merck, Sharp, and Dohme, St. Louis, MO), L$\left[4,5^{-3} \mathrm{H}\right]$ leucine ( $>55 \mathrm{mCi} / \mathrm{mmol}$; Amersham Corp., Arlington Heights, IL), L-[ $\left.1-{ }^{14} \mathrm{C}\right]$ leucine ( $>55 \mathrm{mCi} / \mathrm{mmol}$; Amersham Corp.) sodium $\left[{ }^{14} \mathrm{C}\right]$ bicarbonate and ${ }^{3} \mathrm{H}_{2} \mathrm{O}$ were determined to be pyrogen free (limulus amebocyte lysate) and $>99 \%$ pure and sterile before use $\left[1-{ }^{13} \mathrm{C}\right]$ Leucine and $\left[{ }^{2} \mathrm{H}_{3}\right]$ leucine were determined to be $>95 \%$ enriched by gas chromatography/mass spectrometry (5985B HewlettPackard GC/MS; Hewlett-Packard Co., Palo Alto, CA), and to be exclusively in the L-isomer form (30). Recombinant DNA hGH was supplied by Genentech Inc. (San Francisco, CA) whereas prednisone (Upjohn Co., Kalamazoo, MI) and prednisolone (Hydeltrasol ${ }^{\oplus}$. Merck, Sharp, and Dohme) were obtained from commercial sources.

SUBSTRATE, HORMONE, AND ISOTOPE MEASUREMENT

Plasma leucine and $\alpha$-ketoisocaproate (KIC). Plasma concentrations and ${ }^{3} \mathrm{H}$ and ${ }^{14} \mathrm{C}$ specific activity of $\mathrm{KIC}$ and leucine were determined by high performance liquid chromatography (HPLC) as previously described (31). The enrichments of plasma $\left[1-{ }^{13} \mathrm{C}\right]$ leucine, $\left[{ }^{2} \mathrm{H}_{3}\right]$ leucine, $\left[1-{ }^{13} \mathrm{C}\right] \mathrm{KIC}$, and $\left[{ }^{2} \mathrm{H}_{3}\right] \mathrm{KIC}$ were determined by $\mathrm{GC} / \mathrm{MS}$ using the $t$-butyldimethylsilyl derivative (32). Plasma and meal amino acid concentrations and stable leucine isotope infusate concentrations were determined by ion exchange chromatography (26).

Determinations in urine, stools, and diet. The 24-h urine collections were assayed for creatinine and nitrogen and 24-h stool collections and the diet (breakfast, lunch, and dinner meals combined) were analyzed for nitrogen using methods commercially available through the Department of Laboratory Medicine at the Mayo Clinic.

Determination of ${ }^{14} \mathrm{CO}_{2}$ and ${ }^{13} \mathrm{CO}_{2}$ in expired air. Expired rates of ${ }^{14} \mathrm{CO}_{2}$ were determined by aspirating 2-min collections of expired air through an ethanolamine solution (33). In addition, the specific activity of breath ${ }^{14} \mathrm{CO}_{2}$ was determined at each breath sampling time by aspirating expired air through hydroxide of hyamine (33). Total $\mathrm{CO}_{2}$ production $\left(\mathrm{mmol} \cdot \mathrm{kg}^{-1} \cdot \mathrm{min}^{-1}\right)$ was calculated by dividing expired ${ }^{14} \mathrm{CO}_{2}\left(\mathrm{dpm} \cdot \mathrm{kg}^{-1} \cdot \mathrm{min}^{-1}\right)$ by the ${ }^{14} \mathrm{CO}_{2} \mathrm{SA}\left(\mathrm{dpm} \cdot \mathrm{mmol}^{-1}\right)(33)$.

${ }^{13} \mathrm{CO}_{2}$ enrichments were determined using an automated isotope ratio mass spectrometer $(13,34,35)$. The expired rate of ${ }^{13} \mathrm{CO}_{2}$ was determined by multiplying the ${ }^{13} \mathrm{CO}_{2}$ enrichment by the total $\mathrm{CO}_{2}$ production $\left(\mathrm{nmol} \cdot \mathrm{kg}^{-1} \cdot \mathrm{min}^{-1}\right)$.

Determination of radioactivity. The ${ }^{3} \mathrm{H}$ and ${ }^{14} \mathrm{C}$ radioactivity in $\mathrm{KIC}$ and leucine and ${ }^{14} \mathrm{C}$ radioactivity in $\mathrm{CO}_{2}$ were determined by using a liquid scintillation counter (LS9800 series; Beckman Instruments, Inc., Palo Alto, CA) using dual counting mode, which corrects the radioactivity for both quench and the spillover of ${ }^{14} \mathrm{C}$ radioactivity into the ${ }^{3} \mathrm{H}$ energy spectrum.

\section{Calculations}

The actual rates of stable isotope infusion were determined as the product of the infusate stable isotope concentration, isotope enrichment, and the pump infusion rate. Rates of radiolabeled isotope administration were determined by multiplying the $\mathrm{dpm} \cdot \mathrm{ml}^{-1}$ of infusate by the infusion rate of the pump used $\left(\mathrm{ml} \cdot \mathrm{min}^{-1}\right)$. Estimates of whole body leucine metabolism were made at near substrate and isotopic steady state between 260 and 360 min after starting the leucine tracer infusions using a reciprocal pool model as previously described $(36,37)$. During meal infusion, endogenous rate of appearance of leucine was calculated by subtracting the rate of the enterally infused leucine from the total leucine carbon flux as determined using the ${ }^{14} \mathrm{C}$ data. The systemic availability of leucine was calculated by dividing the $\left[{ }^{14} \mathrm{C}\right]$ leucine rate of appearance $\left(\mathrm{R}_{\mathrm{a}}\right.$, tracer infused systemically) by the $\left.{ }^{13} \mathrm{C}\right]$ leucine $R_{a}$ (tracer infused enterally). The rate of leucine oxidation $\left(\mu \mathrm{mol} \cdot \mathrm{kg} \mathrm{LBM}^{-1} \cdot \mathrm{min}^{-1}\right)$ was calculated as previously described (36) using the $\left[{ }^{14} \mathrm{C}\right] \mathrm{KIC} \mathrm{SA}$ (or $\left[{ }^{13} \mathrm{C}\right] \mathrm{KIC}$ enrichment) and was corrected for the $\mathrm{CO}_{2}$ recovery obtained in each individual during $\mathrm{NaH}^{14} \mathrm{CO}_{3}$ infusions in the postabsorptive (mean value of studies $\mathrm{A}, \mathrm{B}$, and $\mathrm{C}$ ) and the fed state during the course of study protocol $\mathrm{C}$ (see above). ${ }^{14} \mathrm{CO}_{2}$ recovery was calculated by dividing the rate of ${ }^{14} \mathrm{CO}_{2}$ expired in breath by the $\mathrm{NaH}^{14} \mathrm{CO}_{2}$ infusion rate.

Nitrogen balance was calculated by subtracting the meal nitrogen intake from the stool and urine nitrogen losses over the last three outpatient days (days 5, 6, and 7). No corrections were made for skin or other insensible losses. Protein balance was calculated from the nitrogen balance by multiplying the nitrogen balance $(\mathrm{g} / 24 \mathrm{~h})$ by $6.25(38)$. Protein balance was also calculated from the leucine kinetic data assuming that $(a)$ the subjects were in the absorptive phase of digestion for $16 \mathrm{~h} / \mathrm{d}(0700-2300$ hours) and in the postabsorptive phase for $8 \mathrm{~h}$ $(2300-0700$ hours) and $(b) 8 \%$ of all protein is leucine (9). Thus protein balance $\left(\mathrm{g} \cdot \mathrm{kg} \mathrm{LBM}^{-1} \cdot 24 \mathrm{~h}^{-1}\right)$ equals:

$\frac{\text { Leu bal }_{\text {fast }}+2 \times \text { Leu bal }_{\text {fed }}}{3} \times \frac{1440 \times 131.2}{0.08 \times 10^{6}}$,

where LBM is the lean body mass, Leu bal fast $_{\text {and Leu bal }}$ fod are the leucine balance data in $\mu \mathrm{mol} \cdot \mathrm{kg} \mathrm{LBM}{ }^{-1} \cdot \mathrm{min}^{-1}$ in the fasted and fed states, respectively, 1,440 represent $\mathrm{min} / \mathrm{d}, 131.2 \mathrm{~g} / \mathrm{mole}$ of leucine, 0.08 is the fraction of body protein which is leucine and $10^{6}$ converts $\mu \mathrm{mol}$ to $\mathrm{mol}$.

\section{Statistics}

Data are expressed as mean \pm SEM. Groups were compared using ANOVA, and statistical differences among the groups were established using a post hoc Neuman-Keuls test. Comparisons within groups were done using the $t$ test for paired observations. Values were considered to be significantly different with $P$ values less than 0.05 .

\section{Results}

Subjects' characteristics and diet composition (Table I). Body weight did not change as a result of any of the treatments. Body weight, height, and lean body mass were not significantly different among the four groups of subjects studied. Caloric intake and diet composition were not different among the groups investigated.

Plasma glucose, insulin, rhGH, and IGF-I concentrations. The postabsorptive overnight fasting ( $14 \mathrm{~h})$ plasma glucose concentrations overall averaged $95 \pm 2 \mathrm{mg} / \mathrm{dl}$ and were similar in all four groups before initiation of drug and/or placebo treatment. During the $2 \mathrm{~h}$ of blood sampling in study A (postabsorptive state, $22 \mathrm{~h}$ fasting), the plasma glucose concentrations were $77 \pm 3$ and $77 \pm 4 \mathrm{mg} \%$ in the control and rhGH alone treated groups, respectively. In the prednisone and prednisone plus rhGH group, the plasma glucose concentrations (106 \pm 4

Table I. Characteristics of Study Population

\begin{tabular}{lrrrr}
\hline & Control & Prednisone* & rhGH & $\begin{array}{r}\text { Prednisone } \\
+ \text { rhGH }^{* 4}\end{array}$ \\
\hline $\begin{array}{l}\text { Body weight }(\mathrm{kg}) \\
\text { pre }\end{array}$ & & & & \\
$\quad$ post" & $66 \pm 3$ & $73 \pm 4$ & $70 \pm 4$ & $70 \pm 3$ \\
$\begin{array}{l}\text { Lean body weight" }(\mathrm{kg}) \\
\text { Height }(\mathrm{cm})\end{array}$ & $65 \pm 3$ & $73 \pm 3$ & $71 \pm 4$ & $72 \pm 4$ \\
& $171 \pm 2$ & $62 \pm 4$ & $61 \pm 5$ & $65 \pm 3$ \\
& & $174 \pm 3$ & $173 \pm 3$ & $177 \pm 2$ \\
\hline
\end{tabular}

Values are given as mean \pm SEM.

* $0.8 \mathrm{mg}$ prednisone per kilogram body weight.

$\$ 0.1 \mathrm{mg}$ human growth hormone per kilogram body weight.

${ }^{8}$ Fasting body weight on the morning of the first treatment day.

" Fasting value on the morning of the first inpatient study day. 
and $120 \pm 8 \mathrm{mg} \%$, respectively) were higher $(P<0.01$, ANOVA) than those of the other two treatment groups. Plasma glucose concentrations were increased $(P<0.01)$ in all four groups during infusion of the "test meal" on both study days B and C. No differences in plasma glucose concentrations during meal infusion were observed among the control, prednisone alone, and rhGH alone groups $(113 \pm 1,140 \pm 6,124 \pm 3 \mathrm{mg} \%$, respectively, ANOVA); however, during combined treatment with rhGH and prednisone, the plasma glucose concentrations were elevated (204 $\pm 33 \mathrm{mg} \%, P<0.001$, ANOVA). Since study day B and $\mathrm{C}$ were not significantly different, only glucose and hormone data from study day $B$ are provided.

In the postabsorptive state (study A), plasma insulin concentrations were similar (ANOVA) in the control, prednisone alone, and rhGH alone groups $(34 \pm 8,91 \pm 7,52 \pm 6 \mathrm{pmol} / \mathrm{liter}$, respectively), but elevated $(P<0.01)$ in the combined treatment group (237 $\pm 57 \mathrm{pmol} / \mathrm{liter})$. During meal infusion, plasma insulin concentrations were $226 \pm 44 \mathrm{pmol} /$ liter in the control group but elevated $(P<0.01$, ANOVA) in the other three groups of subjects when compared to the control group $(667 \pm 72,564 \pm 65$, and $1,249 \pm 54 \mathrm{pmol} /$ liter, prednisone, rhGH, and combined therapy, respectively). In addition, plasma concentrations of insulin were higher in the combined (rhGH and prednisone) treatment group during meal infusion, when compared to prednisone alone or $\mathrm{rhGH}$ alone treated subjects $(P<0.01)$.

In the postabsorptive state (study A), plasma hGH concentrations measured $20 \mathrm{~h}$ after the last injection were similar in the control, prednisone alone, and combined therapy groups $(4.7 \pm 1.5,2.3 \pm 1.1$, and $3.1 \pm 1.2 \mathrm{ng} / \mathrm{ml}$, respectively), whereas after rhGH treatment alone, the value was elevated $(6.9 \pm 0.6$ $\mathrm{ng} / \mathrm{ml}, P<0.001$, ANOVA). During meal infusion (study B), similar values and statistical relationships were observed $(2.5 \pm 0.8,3.5 \pm 0.5,5.7 \pm 0.7$, and $4.9 \pm 1.0$, respectively, placebo, prednisone alone, rhGH alone, and combined treatment groups; $P<0.05$, ANOVA).

In the postabsorptive state (study A), plasma IGF-I con- centrations were similar in the control and prednisone alone treated subjects $(194 \pm 18$ and $265 \pm 26 \mathrm{ng} / \mathrm{ml}$, respectively). After rhGH treatment alone or in combination with prednisone, IGF-I concentrations were increased $(677 \pm 82,555 \pm 56$ $\mathrm{ng} / \mathrm{ml}$, respectively, $P<0.001$, ANOVA). In the fed state (study B) similar values and statistical relationships were observed (control: $204 \pm 19$, prednisone alone: $309 \pm 25$, rhGH alone: $622 \pm 76$, rhGH and prednisone: $690 \pm 63 \mathrm{ng} / \mathrm{ml}$, respectively).

Plasma leucine and KIC concentrations, SA, and enrichments and ${ }^{14} \mathrm{CO}_{2}$ recovery (Table II). In the postabsorptive state (study A) prednisone alone increased $(P<0.001)$ plasma KIC and leucine concentrations, whereas rhGH decreased $(P$ $<0.001$ ) plasma KIC concentrations when compared to the placebo-treated controls. In the fed state (study B), plasma KIC concentrations were increased $(P<0.01)$ in volunteers receiving combined prednisone and rhGH treatment when compared with those of the control subjects. With the exception of the group treated with combined rhGH and prednisone, KIC plasma concentrations decreased $(P<0.001)$ as a consequence of the test meal administration. After $4 \mathrm{~h}$ of isotope infusion, the plasma concentrations of leucine and KIC and their enrichments and SA were at steady-state, as were the expired breath rates of ${ }^{13} \mathrm{CO}_{2}$ and ${ }^{14} \mathrm{CO}_{2}$ excretion and total $\mathrm{CO}_{2}$ production. The mean steady-state values for each study group (minutes 260 to 360 ) during study $\mathrm{A}, \mathrm{B}$, and $\mathrm{C}$ are depicted in Table II. In the postabsorptive state, ${ }^{14} \mathrm{CO}_{2}$ recovery in expired air during intravenous infusion of sodium $\left[{ }^{14} \mathrm{C}\right]-$ bicarbonate was similar in the four groups of subjects (overall average: $70 \pm 2 \%$ of the infused radioactivity). As a consequence of meal infusion, the ${ }^{14} \mathrm{CO}_{2}$ recovery was increased $(P$ $<0.001$ ) in each group but, again, no differences were observed among the groups (overall average: $86 \pm 2 \%$ ).

Leucine kinetics and plasma amino acid concentrations (Tables III and IV. Postabsorptive (study A). The rate of appearance of leucine into the plasma space was increased in subjects treated with prednisone alone in the postabsorptive

Table II. Infusion Rates of Leucine, Specific Radioactivities, Enrichments, and Plasma Concentrations of Leucine and $\mathrm{KIC}$ and ${ }^{14} \mathrm{CO}_{2}$ Values in Expired Air

\begin{tabular}{|c|c|c|c|c|c|c|c|c|c|c|c|c|}
\hline \multirow[b]{2}{*}{ Study day } & \multicolumn{3}{|c|}{ Control } & \multicolumn{3}{|c|}{ Prednisone } & \multicolumn{3}{|c|}{ rhGH } & \multicolumn{3}{|c|}{ Prednisone + rhGH } \\
\hline & $\mathbf{A}$ & B & $\mathrm{C}$ & A & B & $\mathrm{C}$ & A & B & $\mathrm{C}$ & A & B & $\mathrm{C}$ \\
\hline \multicolumn{13}{|l|}{ Concentrations } \\
\hline Leucine ( $\mu \mathrm{mol} /$ liter $)$ & $140 \pm 9$ & $153 \pm 9$ & $144 \pm 10$ & $172 \pm 11^{\ddagger}$ & $168 \pm 7$ & $170 \pm 10$ & $149 \pm 14$ & $136 \pm 7$ & $131 \pm 8$ & $155 \pm 7$ & $176 \pm 17$ & $167 \pm 18$ \\
\hline $\mathrm{KIC}(\mu \mathrm{mol} /$ liter $)$ & $35 \pm 2$ & $21 \pm 2^{8}$ & $20 \pm 2^{8}$ & $49 \pm 3^{*}$ & $27 \pm 1^{\neq}$ & $28 \pm 2^{\ddagger \S}$ & $25 \pm 3^{*}$ & $18 \pm 2^{\S}$ & $17 \pm 2^{* \$}$ & $40 \pm 3$ & $34 \pm 4^{\ddagger}$ & $33 \pm 3^{\ddagger}$ \\
\hline \multicolumn{13}{|l|}{$\begin{array}{c}\text { Plasma specific activities } \\
\left(\mathrm{dpm} \cdot \mathrm{nmol} \mathrm{l}^{-1}\right)\end{array}$} \\
\hline$\left[{ }^{3} \mathrm{H}\right]$ Leucine & $8.7 \pm 1.0$ & $6.6 \pm 0.4$ & $5.0 \pm 0.4$ & $9.2 \pm 1.3$ & $9.7 \pm 1.3$ & $5.3 \pm 0.5$ & $12.3 \pm 1.3$ & $10.5 \pm 0.9$ & $7.6 \pm 1.7$ & $8.3 \pm 1.4$ & $10.8 \pm 1.3$ & $6.0 \pm 0.4$ \\
\hline$\left[{ }^{3} \mathrm{H}\right] \mathrm{KIC}$ & $7.7 \pm 0.7$ & $5.2 \pm 0.4$ & $3.8 \pm 0.4$ & $8.0 \pm 1.2$ & $7.7 \pm 1.1$ & $3.7 \pm 0.4$ & $11.5 \pm 1.1$ & $9.4 \pm 1.1$ & $4.6 \pm 0.5$ & $7.4 \pm 1.2$ & $8.9 \pm 1.1$ & $4.4 \pm 0.3$ \\
\hline$\left[{ }^{14} \mathrm{C}\right]$ Leucine & $6.5 \pm 0.4$ & $5.0 \pm 0.3$ & - & $6.4 \pm 0.8$ & $7.5 \pm 0.9$ & - & $9.4 \pm 1.0$ & $7.8 \pm 0.9$ & - & $6.7 \pm 0.9$ & $7.5 \pm 0.6$ & - \\
\hline$\left[{ }^{14} \mathrm{C}\right] \mathrm{KIC}$ & $4.8 \pm 0.3$ & $3.5 \pm 0.3$ & - & $4.7 \pm 0.7$ & $5.4 \pm 0.7$ & - & $7.2 \pm 0.7$ & $5.7 \pm 0.7$ & - & $5.0 \pm 0.6$ & $5.4 \pm 0.4$ & - \\
\hline \multicolumn{13}{|l|}{$\begin{array}{l}\text { Enrichments (mole } \\
\quad \text { percent enrichment) }\end{array}$} \\
\hline$\left[{ }^{13} \mathrm{C}\right]$ Leucine & $3.3 \pm 0.2$ & $2.9 \pm 0.2$ & - & $2.9 \pm 0.2$ & $2.3 \pm 0.2$ & - & $2.8 \pm 0.3$ & $2.5 \pm 0.3$ & - & $2.9 \pm 0.1$ & $2.3 \pm 0.1$ & - \\
\hline$\left[{ }^{13} \mathrm{C}\right] \mathrm{KIC}$ & $3.0 \pm 0.2$ & $2.4 \pm 0.2$ & - & $2.6 \pm 0.2$ & $1.9 \pm 0.2$ & - & $2.5 \pm 0.2$ & $2.1 \pm 0.2$ & - & $2.6 \pm 0.1$ & $1.9 \pm 0.1$ & - \\
\hline$\left[{ }^{2} \mathbf{H}_{3}\right]$ Leucine & - & - & $1.9 \pm 0.1$ & - & - & $1.6 \pm 0.2$ & - & - & $1.7 \pm 0.2$ & - & - & $1.7 \pm 0.1$ \\
\hline$\left[{ }^{2} \mathrm{H}_{3}\right] \mathrm{KIC}$ & - & - & $1.4 \pm 0.1$ & - & - & $1.3 \pm 0.1$ & - & - & $1.3 \pm 0.1$ & - & - & $1.5 \pm 0.1$ \\
\hline \multicolumn{13}{|l|}{ Breath } \\
\hline${ }^{13} \mathrm{CO}_{2}{ }^{11}$ & $10.7 \pm 1.2$ & $18.7 \pm 3.0$ & - & $16.7 \pm 1.4$ & $18.7 \pm 1.8$ & - & $7.5 \pm 1.1$ & $10.2 \pm 2.0$ & - & $9.7 \pm 1.5$ & $11.1 \pm 1.9$ & - \\
\hline${ }^{14} \mathrm{CO}_{2}{ }^{\top}$ & $14.3 \pm 1.3$ & $21.1 \pm 1.4$ & - & $19.8 \pm 2.9$ & $37.2 \pm 4.3$ & - & $12.2 \pm 1.9$ & $26.4 \pm 3.4$ & - & $14.4 \pm 1.7$ & $33.5 \pm 2.7$ & - \\
\hline $\mathrm{CO}_{2}$ production $* *$ & $152 \pm 6$ & $175 \pm 6^{\S}$ & - & $133 \pm 7$ & $171 \pm 11^{8}$ & - & $152 \pm 10$ & $167 \pm 6^{8}$ & - & $153 \pm 6$ & $183 \pm 7^{5}$ & - \\
\hline
\end{tabular}

Values are means \pm SEM. $\quad{ }^{*} P<0.001$ compared to controls by ANOVA; ${ }^{\ddagger} P<0.01$ compared to controls by ANOVA; $P<0.01$ compared to fasting values within each group. " $\mathrm{nmol} \cdot \mathrm{kg}^{-1} \cdot \mathrm{min}^{-1} ; 10^{2} \mathrm{dpm} \cdot \mathrm{kg}^{-1} \cdot \mathrm{min}^{-1} ;{ }^{* *} \mu \mathrm{mol} \cdot \mathrm{kg}^{-1} \cdot \mathrm{min}^{-1}$. 
Table III. Effects of Treatment with Human Growth Hormone and/or Prednisone on Leucine Metabolism in Normal Healthy Volunteers ( $n=8$ in each group) in the Postabsorptive State

\begin{tabular}{|c|c|c|c|c|}
\hline & Control & Prednisone* ${ }^{*}$ & $\mathrm{rhGH}^{\ddagger}$ & Prednisone + rhGH $^{* \ddagger}$ \\
\hline Leucine flux ${ }^{\S}$ & $1.96 \pm 0.07$ & $2.25 \pm 0.06^{\prime \prime}$ & $2.08 \pm 0.08$ & $2.13 \pm 0.04$ \\
\hline Leucine oxidation ${ }^{\S}$ & $0.47 \pm 0.03$ & $0.76 \pm 0.06^{\prime}$ & $0.27 \pm 0.02^{\prime}$ & $0.45 \pm 0.03$ \\
\hline Nonoxidative leucine disappearance (NOLD) & $1.49 \pm 0.08$ & $1.49 \pm 0.07$ & $1.81 \pm 0.07^{* *}$ & $1.68 \pm 0.06$ \\
\hline Oxidation/NOLD & $0.33 \pm 0.04$ & $0.53 \pm 0.07^{\pi}$ & $0.15 \pm 0.01^{\pi}$ & $0.28 \pm 0.03$ \\
\hline Systemic availability (\%) & $87 \pm 5$ & $97 \pm 3$ & $87 \pm 5$ & $94 \pm 4$ \\
\hline
\end{tabular}

Values are given as mean $\pm \mathrm{SEM}$ and statistical differences among the groups were estimated using ANOVA. ${ }^{*} 0.8 \mathrm{mg}$ prednisone per kilogram body weight. ${ }^{\ddagger} 0.1 \mathrm{mg}$ human growth hormone per kilogram body weight. ${ }^{\S} \mu \mathrm{mol} \cdot \mathrm{kg}^{-1} \cdot \mathrm{min}^{-1}$, using iv data. $" P<0.05$ of control subjects. " $P<0.01$ of all other groups. ${ }^{* *} P<0.001$ of all other groups.

state $(P<0.05$, ANOVA, Table III). Leucine oxidation, measured using the systemically infused tracer, was decreased $(P$ $<0.01)$ in subjects receiving rhGH alone and was increased $(P$ $<0.01)$ in subjects taking prednisone alone; in contrast, no difference was observed between placebo-treated subjects and volunteers treated with both prednisone and rhGH (Table III). In the postabsorptive state, the rate of leucine oxidation represents net leucine balance, i.e., the difference between the rates of leucine derived from proteolysis and leucine entering body protein (Fig. 1). Similar relationships and statistical differences were observed for the oxidation of the enterally infused $\left[{ }^{13} \mathrm{C}\right]-$ leucine tracer $(0.36 \pm 0.04,0.67 \pm 0.07,0.29 \pm 0.03$, and $0.37 \pm 0.05 \mu \mathrm{mol} \cdot \mathrm{kg}^{-1} \cdot \mathrm{min}^{-1}$ in the placebo, prednisone, rhGH, and prednisone plus rhGH-treated groups, respectively). Nonoxidative leucine disappearance (NOLD), an indicator of whole body protein synthesis, was only increased in subjects treated with rhGH alone. The ratio of leucine oxidation to NOLD, an indicator of whole body leucine catabolism (39), was increased during prednisone treatment alone, decreased with rhGH therapy alone, but unchanged in subjects receiving both rhGH and prednisone when compared to placebo-treated subjects. The systemic availability of enterally infused $\left[{ }^{3} \mathrm{H}\right]$ leucine and $\left[{ }^{13} \mathrm{C}\right]$ leucine was $87 \%$ or greater in all groups, although slightly (but not significantly) higher in both groups treated with prednisone (Table III). For clarity of data presentation, the systemic availability are presented using only the $\left[{ }^{13} \mathrm{C}\right]$ data (similar results were obtained using $\left[{ }^{3} \mathrm{H}\right]$ leucine).

As expected from leucine kinetic data, plasma essential and nonessential amino acid concentrations were increased only in subjects treated with prednisone alone (Table IV).

During meal infusion (study B; Tables IV and V). Total and endogenous rates of appearance of leucine were not different among the groups during the meal infusion (Table V). However, endogenous leucine rate of appearance was de- creased in all four groups investigated in the fed state, when compared to values obtained in the postabsorptive state $(P$ $<0.01$, Tables III and V). In all groups studied, leucine oxidation was greater $(P<0.001)$ during meal infusion than observed in the postabsorptive state $(P<0.001$, Table V). Similar results were obtained using the enterally infused $\left[{ }^{13} \mathrm{C}\right]$ leucine: $0.79 \pm 0.11,1.04 \pm 0.12,0.49 \pm 0.06,0.62 \pm 0.10 \mu \mathrm{mol} \cdot \mathrm{kg}$ $\mathrm{LBM}^{-1} \cdot \mathrm{min}^{-1}$, placebo, prednisone alone, rhGH alone, and combined treatment groups, respectively). As was observed in the postabsorptive state, leucine oxidation was higher $(P$ $<0.05)$ in subjects given prednisone alone and lower $(P$ $<0.05$ ) in those receiving $\mathrm{rhGH}$ alone when compared to control subjects. Subjects receiving rhGH and prednisone had values similar to those of the control group. When compared to the postabsorptive state, NOLD was greater $(P<0.001)$ during meal infusion in all groups of subjects investigated. Subjects given rhGH alone had greater $(P<0.01)$ whole body rates of leucine entering protein (NOLD) when compared with placebo-treated subjects. Again, in subjects receiving combined therapy, NOLD was not different from that of the controls. The mean systemic availability of enterally delivered leucine was $>92 \%$ (using either $\left[{ }^{3} \mathrm{H}\right]$ leucine or $\left[{ }^{13} \mathrm{C}\right]$ leucine as oral trace) during meal infusion and did not differ among the groups of subjects investigated (only values from study day B are depicted, Table V).

While plasma concentrations of essential and nonessential amino acids were not different among the four study groups in the fed state, they were higher during meal absorption when compared to the postabsorptive study period $(P<0.001$, Table IV).

Leucine balance (NOLD minus endogenous leucine rate of appearance) during meal infusion was similar in controls and in subjects treated with both $\mathrm{rhGH}$ and prednisone $(0.26 \pm 0.04$ vs. $0.33 \pm 0.04 \mu \mathrm{mol} \cdot \mathrm{kg} \mathrm{LBM}{ }^{-1} \cdot \mathrm{min}^{-1}$ ) (Fig. 1). In contrast, volunteers receiving prednisone alone exhibited a leucine bal-

Table IV. Effects of Treatment with Human Growth Hormone and/or Prednisone on Amino Acid Concentrations in Normal Healthy Volunteers ( $n=8$ in each group) in the Postabsorptive State

\begin{tabular}{|c|c|c|c|c|c|}
\hline & & Control & Prednisone* & $\mathrm{rhGH}^{\ddagger}$ & Prednisone $+\mathrm{rhGH}^{* *}$ \\
\hline & & \multicolumn{4}{|c|}{ umol/liter } \\
\hline \multirow[t]{2}{*}{ Essential amino acids } & fast & $601 \pm 36$ & $737 \pm 31^{\S}$ & $598 \pm 29$ & $647 \pm 25$ \\
\hline & fed & $990 \pm 43$ & $1100 \pm 45$ & $987 \pm 46$ & $958 \pm 48$ \\
\hline \multirow[t]{2}{*}{ Nonessential amino acids } & fast & $771 \pm 53$ & $893 \pm 54^{\S}$ & $718 \pm 63$ & $778 \pm 30$ \\
\hline & fed & $1852 \pm 122$ & $1921 \pm 119$ & $2018 \pm 94$ & $1691 \pm 80$ \\
\hline
\end{tabular}

Values are expressed as mean $\pm \mathrm{SEM} . \quad * 0.8 \mathrm{mg}$ prednisone per kilogram body weight. ${ }^{\ddagger} 0.1 \mathrm{mg}$ human growth hormone per kilogram body weight. ${ }^{\S} P<0.05$ of controls by ANOVA. 


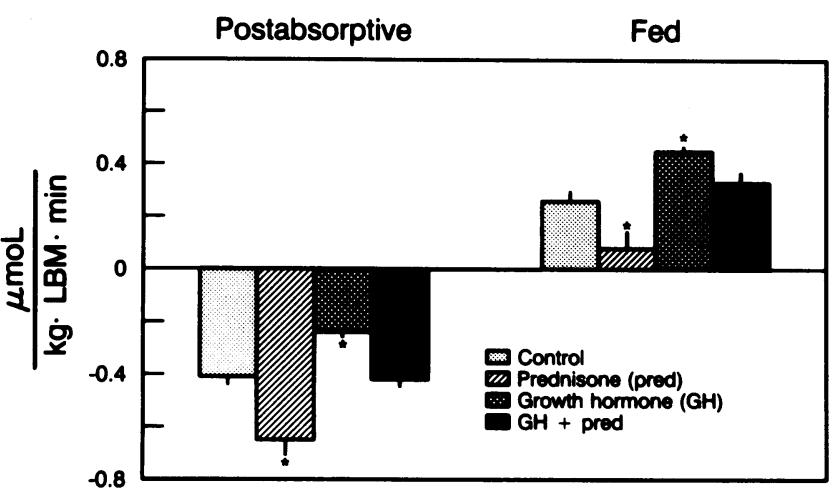

Figure 1. Leucine balance in the postabsorptive (left side) and fed state (right side) in the placebo treated subjects (control), subjects treated with prednisone (pred), recombinant DNA human growth hormone $(\mathrm{GH})$, and combined treatment with $\mathrm{rhGH}$ and prednisone. ${ }^{*} P$ $<0.001$ when compared to placebo treated subjects by ANOVA.

ance which was not significantly different from zero $\left(0.09 \pm 0.06 \mu \mathrm{mol} \cdot \mathrm{kg} \mathrm{LBM}^{-1} \cdot \mathrm{min}^{-1}, P<0.001\right.$ of controls and subjects treated with hGH and prednisone), whereas subjects receiving rhGH alone demonstrated a $70 \%$ higher $\left(0.45 \pm 0.02 \mu \mathrm{mol} \cdot \mathrm{kg} \mathrm{LBM}{ }^{-1} \cdot \mathrm{min}^{-1}\right)$ net leucine balance than placebo-treated control subjects $(P<0.001)$ and volunteers on combined treatment $(P<0.001)$ (Fig. 1).

Protein balance. Using nitrogen balance data, subjects receiving prednisone alone demonstrated negative protein balance $(P<0.001)$ when compared to both control and combined treatment subjects, whereas subjects on rhGH alone exhibited a positive protein balance, 2.5 -fold greater $(P<0.001)$ than the controls. Subjects receiving both prednisone and rhGH treatment had a protein balance similar to that in the placebo-treated control subjects. The leucine kinetic data are not directly comparable with the nitrogen balance values, which reflect net protein balance over an entire 24-h period (i.e., both fasting and fed states). Extrapolating protein balance from the leucine kinetic data (see equation in Methods), similar patterns and significant differences were observed when compared with those derived from the nitrogen balance data (Fig. 2).

\section{Discussion}

The present studies using both traditional nitrogen balance and isotope dilution techniques demonstrate for the first time

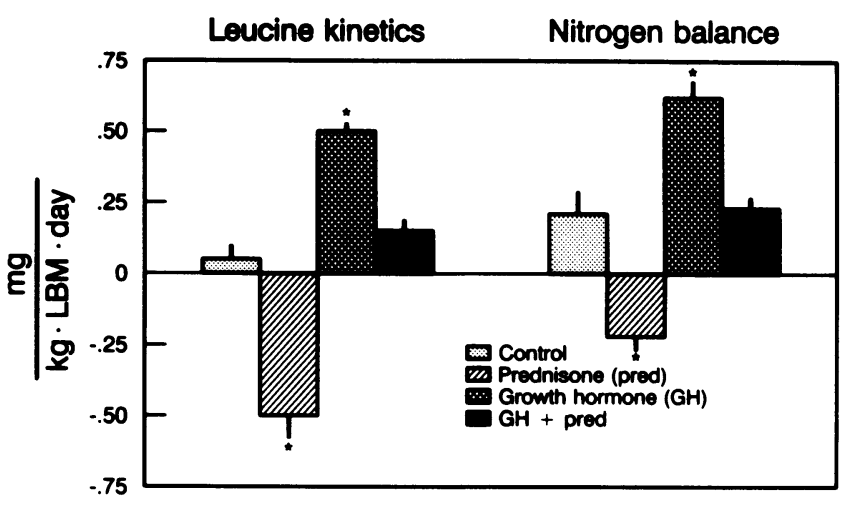

Figure 2. Protein balance calculated from leucine kinetic data (left side) and nitrogen balance (right side) in placebo treated subjects (control), patients treated with prednisone (pred), human growth hormone (GH), and combined treatment with human growth hormone and prednisone. Values are given as milligram of protein per kilogram LBM per day (see Methods for details). ${ }^{*} P<0.001$ when compared to placebo treated subjects by ANOVA.

that the protein catabolic effects of pharmacologic doses of glucocorticosteroids can be prevented by the concomitant administration of rhGH in normal volunteers. Protein catabolism induced by the chronic administration of glucocorticosteroids is implicated in many, if not most, of the complications associated with use of these drugs. The conduct of these studies in normal healthy adult volunteers permitted us to assess the effects of prednisone and/or rhGH on whole body protein metabolism independent of any underlying disease and/or abnormal nutritional states. However, it would be inappropriate to assume that our conclusions can be extended to the wide variety of clinical conditions in which glucocorticoids are used for therapeutic purposes. Rather, the present studies provide reasonable justification for well-controlled prospective trials of rhGH in a number of selected clinical conditions in which the established therapeutic regimen is chronic glucocorticoid administration.

It has long been recognized that rhGH therapy leads to positive nitrogen balance and protein anabolism in both growth hormone deficient children $(15,40)$ and normal adult subjects $(18,22)$. Since nitrogen balance reflects only the net difference between protein synthesis and protein degradation, it has not been established if rhGH inhibits protein breakdown and/or increases protein synthesis in vivo. Using leucine isotope dilution methodology, the present studies demonstrate that $8 \mathrm{~d}$ of

Table V. Effects of Treatment with Human Growth Hormone and/or Prednisone on Leucine Metabolism in Normal Healthy Volunteers ( $n=8$ in each group) in the Fed State

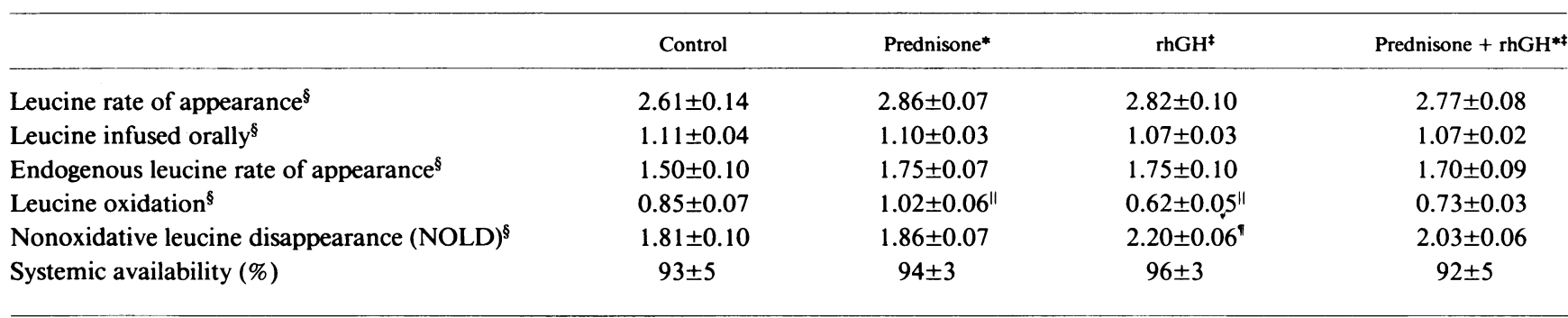

Values are given as mean \pm SEM and statistical differences among the groups are estimated by ANOVA. * 0.8 mg prednisone per kilogram body weight. ${ }^{\ddagger} 0.1 \mathrm{mg}$ human growth hormone per kilogram body weight. ${ }^{\S} \mu \mathrm{mol} \cdot \mathrm{kg}^{-1} \cdot \mathrm{min}^{-1}$, using iv data. $\| P<0.05$ of $\operatorname{control~sub-~}$ jects. " $P<0.01$ of all other groups. 
rhGH therapy result in increased protein synthesis (as indicated by the increment in the nonoxidative leucine disappearance rate), but does not decrease proteolysis (as indicated by the unchanged rate of leucine appearance) (Tables III and V).

The present data provide strong evidence that hGHs effects are mediated in vivo primarily by increasing whole body protein synthesis in both the postabsorptive and fed states. The mechanism(s) by which hGH increases whole body protein synthesis, whether in the presence or absence of glucocorticoid therapy, remains to be established. However, several possible mechanisms should be considered. (a) hGH and prednisone are known to cause insulin resistance with respect to carbohydrate metabolism. Therefore, the protein anabolic effects of rhGH observed in the present study could be mediated through the hyperinsulinemia observed in both the fed and postabsorptive states with combined therapy. However, previous studies $(41,42)$ have demonstrated that a primary effect of insulin on protein metabolism is to decrease proteolysis. In contrast, the administration of rhGH alone or in combination with prednisone in the present study did not affect the rate of appearance of leucine in either the fed or the postabsorptive state and would strongly suggest that the effect of rhGH is not mediated via insulin. (b) Increased plasma and tissue concentrations of both leucine and $\mathrm{KIC}$ have been demonstrated to decrease proteolysis and increase protein synthesis (43). However, the observation that increased protein synthesis induced by rhGH therapy occurred in the presence of normal or low concentrations of these two substrates would suggest that the effect of rhGH on protein synthesis is not leucine or KIC mediated. (c) The most likely mechanism is a direct effect of rhGH and/or IGF-I generated as a result of rhGH administration. Despite daily administration of $\mathrm{rhGH}$, only the plasma concentrations of IGF-I were increased in a sustained fashion suggesting a more likely role for IGF-I in the observed effects of rhGH therapy. Were the effect of rhGH on protein metabolism primarily the result of IGF-I, it would raise questions about the physiologic relevance of recent studies demonstrating decreased proteolysis and protein synthesis as measured by leucine kinetics in rats infused with recombinant IGF-I (44). This question cannot be answered until sufficient amounts of IGF-I are available for clinical trials in humans.

At the present time, several potential drawbacks may exist when combined rhGH and prednisone administration is considered. (a) Using high doses of both $\mathrm{rhGH}$ and prednisone as used in the present studies, carbohydrate intolerance evolved within $8 \mathrm{~d}$. This was an anticipated finding, since both hormones are known to cause insulin resistance (45). Whether reducing the daily dose of $\mathrm{rhGH}$ would preserve its anabolic effect but decrease its adverse effect on carbohydrate metabolism remains to be established. (b) rhGH has been shown in the present (data not shown), as well as in previous studies to increase glomerular filtration rates (46). Recent attention has been drawn to the progression of renal failure associated with glomerular hyperfiltration (47). Therefore, this potential longterm side effect must be considered in the design of any prospective trial using rhGH. (c) A known side effect of excessive hGH in adults is acromegaly and must be considered as a potential risk of therapy when long-term pharmacologic studies are entertained.

The present studies provide a rationale for the evaluation of rhGH in selective disease conditions in which short-term high dose glucocorticoids are used (lupus erythematosus, pemphigus, acute renal allograft rejection, etc.). However, the steroid dose used in the present study was nearly four times that usually prescribed to control a variety of underlying disease processes on a chronic basis. Therefore, it will be necessary to explore the effective dose of $\mathrm{rhGH}$ which may reverse the protein catabolic effects known to occur with chronic low dose glucocorticoid therapy (1-5) and to determine whether these effects are preserved over time (20). This presumed lower preventive dose of rhGH may decrease the risk of rhGH-associated side effects without compromising the beneficial effect on protein metabolism.

\section{Acknowledgments}

We thank Peter Berg, Collette Schmidt, Bethany Krom, Joan Aikens, Joan King, Michelle Miller, Martha Christensen, and Carine HorberFeyder for their technical assistance; and Pat Voelker for her secretarial assistance. We thank Drs. John Miles and Michael Jensen for their helpful critiques of these studies and this manuscript.

This study was supported by U. S. Public Health Service grants DK 26989, DK 24085, and RR-0585, a grant from Genentech, Inc., and by the Mayo Foundation. F. F. Horber was supported by the Swiss National Foundation for Scientific Research.

\section{References}

1. Munro, H. N. 1964. General aspects of the regulation of protein metabolism by diet and by hormones. In Mammalian Protein Metabolism. H. N. Munro and J. B. Allison, editors. Academic Press, Inc., New York. 381-481.

2. Horber, F. F., J. R. Scheidegger, B. E. Gruenig, and F. J. Frey. 1985. Thigh muscle mass and function in patients treated with glucocorticoids. Eur. J. Clin. Invest. 15:302-307.

3. Horber, F. F., J. R. Scheidegger, and F. J. Frey. 1985. Overestimation of renal function in glucocorticosteroid treated patients. Eur. J. Clin. Pharmacol. 28:537-541.

4. Horber, F. F., R. M. Zuercher, H. Herren, M. A. Crivelli, G. Robotti, and F. J. Frey. 1986. Altered body fat distribution in patients with glucocorticoid treatment and in patients on long-term dialysis. Am. J. Clin. Nutr. 43:758-769.

5. Axelrod, L. 1976. Glucocorticoid therapy. Medicine (Baltimore). 55:39-45.

6. Horber, F. F., J. R. Scheidegger, B. E. Gruenig, and F. J. Frey. 1985. Evidence of prednisone-induced myopathy is reversed by physical training. J. Clin. Endocrinol. Metab. 61:83-88.

7. Garrel, D. R., P. D. Delmas, C. Welsh, M. J. Arnaud, S. E. Hamilton, and M. M. Pugeat. 1988. Effects of moderate physical training on prednisone-induced protein wasting: a study of whole-body and bone protein metabolism. Metab. Clin. Exp. 37:257-262.

8. Horber, F. F., H. Hoppeler, J. R. Scheiddegger, H. Herren, H. Howald, and F. J. Frey. 1987. Impact of physical training on the ultrastructure of mid-thigh muscle in normal subjects and in patients treated with glucocorticoids. J. Clin. Invest. 79:1181-1190.

9. Block, R. J. 1956. Amino Acid Handbook. Charles C Thomas Publisher, Springfield, IL. 344 pp.

10. Golden, M. H. N., and J. C. Waterlow. 1977. Total protein synthesis in elderly people: a comparison of results with $\left[{ }^{15} \mathrm{~N}\right] g l y c i n e$ and $\left[{ }^{14} \mathrm{C}\right]$ leucine. Clin. Sci. Mol. Med. 53:277-288.

11. Shamoon, H. P., V. Soma, and R. S. Sherwin. 1980. The influence of acute physiological increments of cortisol on fuel metabolism and insulin binding on monocytes in normal humans. J. Clin. Endocrinol. Metab. 50:495-501.

12. Simmons, P. S., J. M. Miles, J. E. Gerich, and M. W. Haymond. 1984. Increased proteolysis: an effect of increases in plasma cortisol within the physiologic range. J. Clin. Invest. 73:412-420.

13. Beaufrere, B., F. F. Horber, W. F. Schwenk, H. M. Marsh, D. Matthews, J. E. Gerich, and M. W. Haymond. 1989. Glucocorticosteroids increase leucine oxidation and impair leucine balance in humans. Am. J. Physiol. 257:E712-E721. 
14. Tanner, J. M., P. C. R. Hughes, and R. H. Whitehouse. 1977. Comparative rapidity of response of height, limb muscle and limb fat to treatment with human growth hormone in patients with and without growth hormone deficiency. Acta Endocrinol. 84:681-696.

15. Uthne, K., C. R. Reagan, L. P. Gimpel, and J. L. Kostyo. 1974. Effects of human somatomedin preparations on membrane transport and protein synthesis in the isolated rat diaphragm. J. Clin. Endo crinol. Metab. 39:548-554.

16. Liljdahl, S. O., C. A. Gemzell, L. O. Plantin, and G. Birke. 1961. Effect of human growth hormone in patients with severe burns. Acta Chir. Scand. 122:1-14.

17. Wilmore, D. W., J. A. Maylan, Jr., B. F. Bristow, A. D. Mason, Jr., and B. A. Pruitt, Jr. 1974. Anabolic effects of growth hormone and high caloric feedings following thermal injury. Surg. Gynecol. Obstet. 138:875-884.

18. Manson, J. M., and D. W. Wilmore. 1986. Positive nitrogen balance with human growth hormone and hypocaloric intravenous feeding. Surgery. 100:188-197.

19. Clemmons, D. R., R. Williams, D. K. Snyder, and L. E. Underwood. 1987. Treatment with growth hormone conserves lean body mass during dietary restriction in obese volunteers. J. Clin. Endocrinol. Metab. 64:878-883.

20. Snyder, D. K., D. R. Clemmons, and L. E. Underwood. 1988. Treatment of obese, diet-restricted subjects with growth hormone for 11 weeks: effects of anabolism, lipolysis, and body composition. $J$. Clin. Endocrinol. Metab. 67:54-61.

21. Ziegler, T. R., L. S. Young, J. M. Manson, and D. W. Wilmore. 1988. Metabolic effects of recombinant human growth hormone in patients receiving parenteral nutrition. Ann. Surg. 208:6-15.

22. Crist, D. M., G. T. Peake, P. A. Egan, and D. L. Waters. 1988 Body composition response to exogenous GH during training in highly conditioned adults. J. Appl. Physiol. 65:579-584.

23. Jensen, M. D., J. Braun, R. Vetter, and H. M. Marsh. 1988. Measurement of body potassium with a whole body counter: relationship between lean body mass and resting energy expenditure. Mayo Clin. Proc. 864-868.

24. Abumrad, N. N., D. Rabin, M. P. Diamond, and W. W. Lacy. 1981. Use of a heated superficial hand vein as an alternative site for the study of glucose and alanine kinetics in man. Metabolism. 30:936940.

25. Jackson, R., N. Peters, V. Advani, G. Perry, J. Rogers, W. Brough, and T. Pilkington. 1973. Forearm glucose uptake during oral glucose tolerance test in normal subjects. Diabetes. 24:442-448.

26. Stacey-Schmidt, C., P. Berg, and M. W. Haymond. 1982. Use of D-glucosaminic acid as an internal standard in single column accelerated amino acid analysis. Anal. Biochem. 123:74-77.

27. Herbert, V., K. S. Lau, C. W. Gottlieb, and S. J. Bleicher. 1976. Coated charcoal immunoassay of insulin. J. Clin. Endocrinol. Metab. 25:1375-1384.

28. Peak, G. 1974. Growth hormone. In Methods of Hormone Radioimmunoassay. B. Jaffe and H. Behrman, editors. Academic Press, Inc., New York. 103-121.

29. Rosenfeld, R. G., D. M. Wilson, P. D. K. Lee, and R. L. Hintz. 1986. Insulin-like growth factors I and II in evaluation of growth retardation. J. Pediatr. 109:428-433.

30. Nakaparksin, S., E. Gile-Av, and J. Oro. 1970. Study of the racemation of neutral $\mathrm{L}$-alpha amino acids in acid solution using gas chromatographic techniques. Anal. Biochem. 33:374-382.

31. Horber, H. H., J. Kahl, L. Lecavalier, B. Krom, and M. W. Haymond. 1989. Determination of leucine and $\alpha$-ketoisocaproic acid concentrations and specific activity in plasma and leucine specific activities in proteins using HPLC. J. Chromatogr. 495:81-94.

32. Schwenk, W. F., P. J. Berg, B. Beaufrere, J. M. Miles, and M. W. Haymond. 1982. Use of t-butyldimethylsilylation in GC/MS analysis of physiologic compounds in plasma using electron impact ionization. Anal. Biochem. 141:101-109.

33. Nissen, S., and M. W. Haymond. 1986. Changes in leucine kinetics during meal absorption: effects of dietary leucine availability. Am. J. Physiol. 250:E695-E701.

34. Schoeller, D. A., and P. D. Klein. 1979. A microprocessor controlled mass spectrometer for the fully automated purification and isotopic analysis of breath carbon dioxide. Biomed. Mass Spectrom. 6:350-355.

35. Staten, M. A., D. M. Bier, and D. E. Matthews. 1984. Regulation of valine metabolism in man. A stable isotope study. Am. J. Clin. Nutr. 40:1224-1230.

36. Schwenk, W. F., B. Beaufrere, and M. W. Haymond. 1985. Use of reciprocal pool specific activities to model leucine metabolism in humans. Am. J. Physiol. 249:E646-E650.

37. Horber, F. F., C. M. Horber-Feyder, S. Krayer, W. F. Schwenk, and M. W. Haymond. 1989. Plasma reciprocal pool specific activity predicts that of intracellular free leucine for protein synthesis. Am. J. Physiol. 257:E385-E399.

38. Felber, J. P., E. Ferrannini, A. Golay, H. U. Meyer, D. Theibaud, B. Curchod, E. Maeder, E. Jequier, and R. A. DeFronzo. 1987. Role of lipid oxidation in pathogenesis of insulin resistance of obesity and type II diabetes. Diabetes. 36:1341-1350.

39. Horber, F. F., S. Krayer, K. Rehder, and M. W. Haymond. 1988. General anesthesia with halothane and nitrous oxide alters protein and amino acid metabolism in dogs. Anesthesiology. 69:319-326.

40. Cheek, D. B., and D. E. Hill. 1970. Muscle and liver cell growth role of hormone and nutritional factors. Fed. Proc. 29:1503-1509.

41. Fukagawa, N. K., K. L. Minaker, W. Rowe, M. N. Goodman, D. E. Matthews, D. M. Bier, and V. R. Young. 1985. Insulin-mediated reduction of whole body protein breakdown. Dose-response effects on leucine metabolism in postabsorptive man. J. Clin. Invest. 76:23062311.

42. Tessari, P., R. Trevisan, S. Inchiostro, G. Biolo, R. Nosadini, S. V. DeKreutzenberg, E. Duner, A. Tiengo, and G. Crepaldi. 1986. Dose-response curves of effects of insulin on leucine kinetics in humans. Am. J. Physiol. 251:E334-E342.

43. Fulks, R. M., J. B. Li, and A. L. Goldberg. 1975. Effects of insulin, glucose and amino acids on protein turnover in rat diaphragm. J. Biol. Chem. 250:290-298.

44. Jacob, R., E. Barret, G. Piewe, K. D. Fagin, and R. S. Sherwin. 1989. Acute effects of insulin-like growth factor I on glucose and amino acid metabolism in the awake fasted rat. J. Clin. Invest. 83:1717-1723.

45. Rizza, R. A., L. J. Mandarino, and J. E. Gerich. 1982. Cortisol induced insulin resistance in man. Impaired suppression of glucose production and stimulation of glucose utilization due to a postreceptor defect of insulin. J. Clin. Endocrinol. Metab. 54:131-138.

46. Hirschberg, R., and J. D. Kopple. Effects of human growth hormone on GFR and renal plasma flow in man. Kidney Int. Suppl. 22:S15-S20.

47. Brenner, M. B., T. W. Meyer, and T. H. Hostetter. 1982 Dietary protein intake and the progressive nature of kidney disease: the role of hemodynamically mediated glomerular injury in the pathogenesis of progressive glomerular necrosis in aging, renal ablation and intrinsic renal disease. $N$. Engl. J. Med. 307:652-659. 